\title{
Konsep diri membaca dan minat baca pada siswa sekolah dasar
}

\section{Roy Gustaf Tupen Ama ${ }^{1}$ dan Rahma Widyana ${ }^{1}$}

\begin{abstract}
Reading interest is very important for students in the learning process. This study aimed to determine the correlations between reading self-concept and students' reading interest. In this study, the researcher used two scales namely scale of reading self-concept, and scale of students' interest in reading. The population in this study were all students of grade 3,4,5 at "X" Sleman Elementary School in Yogyakarta, Indonesia. The sampling technique in this study was incidental sampling with a sample size of 124 . The results of the analysis show that there is a correlation between reading selfconcept and students' reading interest with an $r$ value of $0.855(p<0.01)$. It is important for elementary school students to form a reading self-concept so that a high reading self-concept will increase students' reading interest.
\end{abstract}

\section{Keywords}

Reading interest, reading self-concept, elementary school students

\section{Pendahuluan}

Pendidikan merupakan salah satu kebutuhan hidup manusia yang paling penting dan mendasar. Kenyataan ini telah dengan sangat cermat diidentifikasi dan dipahami oleh para pendiri bangsa Indonesia. Pendidikan tidak terlepas dari proses belajar. Belajar merupakan proses multidimensional yang melibatkan interaksi yang di dalamnya ada minat dan motivasi yang memuat nilai, tujuan, keyakinan dalam belajar serta dipengaruhi oleh proses kognitif (Chen et al., 2014).

Salah satu cara terbaik untuk belajar yaitu dengan membaca. Membaca merupakan sebuah keterampilan yang harus dimiliki dan dikuasai oleh semua lingkup praktisi pendidikan (Susilowati, 2016). Oleh karena itu dengan melakukan kegiatan membaca akan mengantarkan siswa mendapat banyak pengetahuan serta sukses meraih prestasi dalam belajar. Selain itu membaca akan menjadikan individu yang berkualitas dari segi wawasan dan cara berpikir (Dalman, 2013).

Minat baca adalah keinginan yang kuat dimiliki individu yang diikuti dengan usaha-usaha dalam proses membaca (Rahim, 2008). Minat baca diartikan sebagai sebuah aktivitas dalam bentuk dorongan dalam diri individu dalam memahami kata demi kata dan isi dari sebuah bacaan, dengan penuh ketekunan, kesadaran, dan rasa senang (Dalman, 2013). Darmono (2007) memberi pengertian bahwa minat baca adalah kecenderungan jiwa yang kuat untuk melakukan kegiatan membaca dengan tujuan tertentu oleh individu. Aspek-aspek minat baca yang harus dimiliki seorang siswa adalah kesadaran akan manfaat dari membaca, perhatian tinggi terhadap kegiatan membaca, memiliki rasa senang dalam kegiatan membaca dan frekuensi dalam melakukan kegiatan membaca (Harris \& Sippay, 1980).

Budaya membaca di Indonesia masih tergolong lemah. Menurut hasil survei UNESCO (United Nations Educational Scientific and Cultural Organization) menyatakan bahwa minat baca masyarakat Indonesia sangat memprihatinkan, hanya $0,001 \%$. Artinya dari 1.000 orang Indonesia, hanya 1 orang yang rajin membaca. Minat baca Indonesia berada di peringkat 60, hanya satu tingkat di atas Botswana, salah satu negara di Afrika yang berada di peringkat 61 (Anggraeni, 2019). Penelitian yang dilakukan oleh Antari, Sundari, \& Wulan (2016) mengenai studi deskriptif minat baca siswa SD di Kota Tangerang menghasilkan bahwa kategori minat baca siswa berada pada kategori rendah sebanyak $40 \%$ dan kategori sedang sebanyak $60 \%$. Rendahnya minat baca tersebut dikarenakan kesadaran membaca, kesenangan membaca, dan kebiasaan membaca yang rendah.

Selanjutnya, peneliti melakukan wawancara di SDN " $X$ " Sleman - Yogyakarta. Wawancara dilakukan terhadap 10 orang siswa yang mewakili kelas 3, 4, dan 5. Hasil wawancara terhadap 10 orang siswa tersebut diketahui terdapat siswa yang memiliki minat baca rendah. Pada aspek kesadaran akan membaca tergolong masih rendah, siswa mengatakan bahwa jika disuruh orang tua ataupun guru barulah siswa tersebut mau membaca buku. Siswa lain mengatakan bahwa karena disuruh dan dipaksa guru untuk membaca sehingga siswa mau tidak mau terpaksa untuk membaca buku di kelas karena takut dimarahi oleh guru. Saat berada di rumah siswa mengatakan memilih menonton TV daripada membaca buku karena orang tua tidak menyuruh untuk membaca. Siswa lain mengatakan saat di rumah orang tua jarang melakukan kegiatan membaca buku sehingga siswa mengatakan tidak perlu untuk membaca buku karena orang tua juga tidak membaca buku.

${ }^{1}$ Universitas Mercu Buana Yogyakarta

\section{Korespondensi:}

Roy Gustaf Tupen Ama, Program Studi Magister Psikologi, Fakultas Psikologi, Universitas Mercu Buana Yogyakarta

Email: royama27@gmail.com 
Pada aspek perhatian yaitu sejauh mana siswa memiliki perhatian dan ketertarikan dalam membaca diketahui terdapat siswa yang memiliki perhatian yang rendah dalam membaca buku. Siswa mengatakan saat membaca sering tidak berkonsentrasi dan tidak fokus dalam membaca buku apalagi membaca buku-buku pelajaran dan pengetahuan. Siswa mengatakan biasanya meminta temannya membacakan isi bacaan dari buku kemudian dijelaskan kembali kepada siswa tersebut mengenai isi bacaannya karena perhatian yang rendah terhadap isi bacaan.

Pada aspek rasa senang yaitu seberapa besar rasa senang subjek terhadap kegiatan membaca, siswa mengatakan cepat bosan saat membaca buku, aktivitas luang di rumah siswa tersebut memilih untuk bermain games bersama temanteman atau tetangga rumah. Siswa yang lain mengatakan bahwa saat ada jam kosong di kelas siswa memilih untuk bercerita dan bercanda bersama teman-teman daripada ke perpustakaan untuk membaca buku.

Pada aspek frekuensi yaitu mengungkap seberapa sering subjek melakukan aktivitas membaca buku diketahui siswa jarang membaca buku, siswa mengatakan melakukan aktivitas membaca hanya pada saat mau ujian atau diberikan tugas dari guru dan disuruh oleh guru untuk membaca. Siswa mengatakan malas untuk mengunjungi perpustakaan sekolah untuk membaca buku saat waktu luang.

Mokoagow (2016) mengatakan bahwa individu diharapkan memiliki minat baca yang tinggi karena dengan minat baca yang tinggi akan mampu menyerap berbagai informasi dan ilmu pengetahuan. Kemampuan serta minat baca yang tinggi adalah modal dasar untuk keberhasilan siswa dalam berbagai mata pelajaran serta kemajuan dalam pendidikan.

Penelitian tentang minat baca perlu dilakukan karena minat baca yang tinggi penting dalam keberhasilan belajar. Minat baca memiliki dampak dan pengaruh yang baik bagi siswa dalam proses belajar. Berdasarkan hasil penelitian Sabriyadi et al. (2015) bahwa ada hubungan yang signifikan antara minat baca dengan prestasi belajar. Selain itu penelitian Marlina et al. (2017) menemukan bahwa ada hubungan signifikan antara minat baca dengan hasil belajar. Siswa memiliki minat baca dalam proses belajar mengajar akan cepat mengerti dan mudah mengingat setiap pelajaran sehingga menghasilkan hasil belajar dan prestasi yang baik. Minat baca yang ada pada siswa akan menjadikannya lebih tahu dan paham terhadap materi pelajaran. Siswa yang mempunyai hasrat atau keinginan untuk membaca akan mempunyai wawasan yang luas, karena selalu mendapatkan hal-hal terbaru dari hasil bacaannya. Hal ini juga sejalan dengan penelitian yang dilakukan oleh Adam (2017) bahwa minat baca memiliki hubungan yang sangat signifikan dengan prestasi belajar. Semakin tinggi minat baca maka semakin tinggi pula prestasi belajar siswa. Berdasarkan beberapa penelitian di atas, disimpulkan bahwa jika seorang siswa memiliki minat baca yang tinggi maka akan diikuti pula dengan prestasi belajar yang tinggi dan sebaliknya, jika siswa memiliki minat baca yang rendah maka prestasi belajar pun ikut rendah.

Faktor-faktor yang mempengaruhi minat baca yaitu, intelegensi, kemampuan membaca, sikap terhadap membaca (Harris \& Sippay, 1980), konsep diri (Denessen, Zarret, \& Ecless , 2007), usia, jenis kelamin (Stoodt et al., 1996). Faktor yang dipilih dalam penelitian ini yaitu konsep diri membaca. Chapman \& Tunmer (1995) menjelaskan konsep diri membaca merupakan suatu bagian atau sub area dari konsep diri akademik yang merupakan gambaran tentang diri atau penilaian diri seseorang dalam proses membaca dengan mengkombinasikan proses persepsi kompetensi dalam melakukan tugas membaca, sulit atau mudah dalam proses membaca, dan sikap dirasakan terhadap membaca. Aspek-aspek konsep diri membaca mencakup persepsi kompetensi membaca, persepsi kesulitan membaca, serta sikap terhadap membaca (Chapman \& Tunmer, 1995). Hal ini sejalan dengan penelitian yang dilakukan Walgermo et al. (2018) bahwa siswa yang memiliki konsep diri membaca yang positif akan memberikan dampak terhadap tingginya minat baca siswa.

Minat baca merupakan suatu kajian yang telah berlangsung dalam waktu ke waktu. Devi \& Shanti (2004), menambahkan bahwa pada usia 6-12 tahun yaitu saat anak berada pada masa kanak-kanak adalah masa yang tepat untuk mulai mengembangkan minat membaca pada anak. Pada usia ini, kemampuan anak memahami bahasa dalam buku bacaan berkembang dengan pesat. Menurut Kartono (1995), bahwa usia (7-13 tahun) ini merupakan usia SD, mulai memandang semua peristiwa dengan objektif, unsur intelektual (kognitif) dan akal budi (moral) terjalin semakin menonjol dan emosionalitas menjadi berkurang. Semua kejadian ingin diselidiki dengan tekun dan penuh minat. Pada penelitian ini yang menjadi perbedaan khusus atau kekhasannya adalah peneliti meneliti minat baca pada siswa sekolah dasar dimana berbeda dengan penelitian-penelitian sebelumnya yang meneliti pada subjek penelitian SMP dan SMA.

Tujuan penelitian ini adalah untuk mengetahui hubungan antara konsep diri membaca dengan minat baca pada siswa sekolah dasar. Manfaat yang diharapkan dari penelitian ini adalah dapat memberikan sumbangsih bagi ilmu psikologi khususnya psikologi pendidikan, serta dapat memberikan manfaat secara praktis bagi sekolah, guru, orang tua dan peneliti selanjutnya untuk dapat meningkatkan minat baca siswa.

Hipotesis yang diajukan dalam penelitian ini yaitu "ada hubungan positif antara konsep diri membaca dengan minat baca siswa". Semakin positif konsep diri membaca, maka semakin tinggi minat baca siswa, sebaliknya, semakin negatif konsep diri membaca, maka semakin rendah minat baca pada siswa.

\section{Metode}

\section{Subjek Penelitian}

Populasi dalam penelitian ini adalah seluruh kelas Kelas 3, 4 dan 5 dengan jumlah 180 siswa/i SDN "X" Sleman Yogyakarta. Penentuan sampel dengan menggunakan teknik incidental sampling. Adapun karakteristik sampling yaitu siswa sekolah dasar kelas 3, 4, dan 5, berjenis kelamin perempuan dan laki-laki, rentang usia 8 sampai dengan 11 tahun, sudah lancar membaca, dan tinggal bersama orangtua. Pengambilan sampel dilakukan secara online melalui google form, dengan pertimbangan bahwasanya penelitian ini dilakukan dimasa pandemi covid-19, sehingga tidak menungkinkan terjadi interaksi langsung. Penelitian ini melibatkan 124 subjek penelitian yang diambil dari SDN "X" Sleman - Yogyakarta. Usia subjek terdiri dari 
8 tahun sebanyak 30 orang, 9 tahun sebanyak 31 orang, 10 tahun sebanyak 30 orang, 11 tahun sebanyak 33 orang. Berdasarkan kategori jenis kelamin, terdapat sebanyak 61 orang subjek laki-laki dan 63 orang subjek perempuan.

\section{Variabel dan Instrumen Penelitian}

Penelitian ini terdiri dari dua variabel, satu variabel tergantung yaitu minat baca dan satu variabel bebas yaitu konsep diri membaca. Minat baca didefinisikan sebagai keinginan kuat yang timbul dari dalam diri individu disertai dengan usaha-usaha yang dilakukan oleh individu dalam proses membaca. Minat baca diungkap menggunakan skala minat baca yang disusun sendiri oleh peneliti dengan mengacu pada teori Harris \& Sippay (1980) yang telah diterjemahkan oleh Nursalina \& Budiningsih (2014) yang terdiri dari empat aspek yaitu, (1) aspek kesadaran yakni seberapa jauh subjek menyadari, mengetahui, dan memahami manfaat membaca, (2) aspek perhatian yaitu mengungkap perhatian dan ketertarikan subjek dalam membaca buku, (3) aspek rasa senang yaitu aspek yang mengungkap seberapa besar rasa senang subjek terhadap kegiatan membaca, dan (4) aspek frekuensi yaitu aspek yang mengungkap seberapa sering subjek melakukan aktivitas membaca buku. Reliabilitas skala minat baca diperoleh Alpha sebesar 0,972 dan nilai daya beda item dari 0.322 sampai 0,732 .

Konsep diri membaca merupakan gambaran tentang diri sendiri atau penilaian diri seseorang dalam proses membaca pada dirinya sendiri. Konsep diri membaca diungkap menggunakan skala konsep diri membaca yang dirancang oleh peneliti dengan mengacu dan memodifikasi skala Reading Self-Concept Scale (RSCS) oleh Chapman \& Tunmer (1995) yang terdiri dari tiga aspek yaitu, (1) aspek kompetensi membaca yakni keyakinan individu terhadap dirinya sendiri dalam menilai tentang kemampuan dan kecakapannya dalam proses dan tugas membaca, (2) aspek persepsi kesulitan membaca yakni keyakinan bahwa kegiatan membaca itu terkadang ada kesulitannya, dan (3) aspek sikap membaca yakni komponen afektif dalam membaca, yang digambarkan dalam hal perasaan dan afinitas untuk membaca. Reliabilitas skala konsep diri membaca sebesar 0,901 . Kemudian nilai daya beda aitem bergerak dari 0.360 sampai 0,721 .

Kedua instrumen pada penelitian ini diukur menggunakan skala likert yang disusun dengan item pendukung (favorable) dan tidak mendukung (unfavorable). Pada setiap pernyataan terdapat empat alternatif pilihan jawaban, yaitu Sangat Setuju (SS), Setuju (S), Tidak Setuju (TS), Sangat Tidak Setuju (STS). Pada item favorable diberi skor 4 untuk SS (Sangat Setuju), nilai 3 untuk (S) Setuju, nilai 2 untuk Tidak Setuju (TS), dan nilai 1 untuk Sangat Tidak Setuju (STS). Sedangkan pada item yang tidak mendukung (unfavorable), skor diberikan sebaliknya yaitu skor 1 untuk nilai untuk SS (Sangat Setuju), nilai 2 untuk (S) Setuju, nilai 3 untuk Tidak Setuju (TS), dan nilai 4 untuk Sangat Tidak Setuju (STS).

\section{Analisis Data}

Teknik analisis data yang dipakai yaitu analisis product moment untuk melihat korelasi antara variabel bebas dan variabel tergantung.

\section{Hasil}

Sebelum dilakukan uji korelasi maka dilakukan analisis deskriptif data penelitian dan uji prasyarat terlebih dahulu. Pengkategorisasian data dengan klasifikasi tinggi, rendah, dan sedang dari masing-masing variabel akan dijelaskan berikut ini.

Siswa yang memiliki minat baca kategori rendah (interval skor $\mathrm{x}<77.5)$ sebanyak 8 orang $(6.5 \%)$, kategori sedang (interval skor $77.5<\mathrm{x}<108.5$ ) sebesar 80.6\% (100 orang), dan kategori tinggi (interval skor $\mathrm{x}>108.5$ ) sebesar $12.9 \%$ (16 orang). Dapat disimpulkan bahwa variabel minat baca siswa adalah sedang. Siswa yang memiliki konsep diri membaca kategori rendah (interval skor $\mathrm{x}<46.00$ ) sebanyak 0 orang $(0.0 \%)$, kategori sedang (interval skor $46.00<\mathrm{x}$ $<69.00$ ) sebesar $45.2 \%$ (56 orang), dan kategori tinggi (interval skor $x>69.00$ ) sebesar $54.8 \%$ (68 orang). Dapat disimpulkan bahwa variabel konsep diri membaca adalah tinggi.

Selanjutnya peneliti melakukan uji asumsi yang terdiri dari uji normalitas dan linieritas. Uji normalitas minat baca didapatkan nilai KSZ sebesar $1.240 \quad(p=0.092)$. Hal tersebut menunjukkan bahwa variabel minat baca berdistribusi normal. Uji normalitas konsep diri membaca didapatkan nilai KSZ sebesar $1.257(p=0.085)$. Hal tersebut menunjukkan bahwa variabel konsep diri membaca pada siswa berdistribusi normal.

Hasil uji linieritas diperoleh hasil variabel konsep diri membaca mempunyai nilai $F$ sebesar 328.243 dengan signifikansi pada liniarity $(p<0.01)$, sehingga dapat disimpulkan bahwa antara variabel konsep diri membaca dan minat baca terdapat hubungan yang linier. Hasil uji prasyarat analisis yaitu uji normalitas dan uji linieritas menunjukkan bahwa data penelitian berdistribusi normal dan linier, maka analisis data untuk pengujian hipotesis dalam penelitian ini dapat diteruskan dengan menggunakan analisis korelasi product moment. Hasil pengujian hipotesis mengenai hubungan konsep diri membaca dengan minat baca pada siswa didapatkan nilai koefisien korelasi product moment sebesar $0.855(p<0.000)$, yang ini berarti hipotesis diterima.

\section{Diskusi}

Hasil pengujian hipotesis menggunakan teknik korelasi product moment yang menunjukkan angka korelasi sebesar $0.855(p<0.01)$. Hasil ini menunjukkan bahwa hipotesis diterima, artinya ada hubungan positif dan sangat signifikan antara konsep diri membaca dengan minat baca. Chapman \& Tunmer (1995) menjelaskan bahwa konsep diri membaca yang positif dimiliki individu memiliki dampak positif dalam peningkatan minat baca siswa, karena individu akan menilai proses membaca yang dilakukannya sendiri, semakin positif gambaran konsep diri membaca yang dimiliki individu akan meningkatkan minat dan motivasi membaca pada anak. Schiefele et al. (2012) menjelaskan bahwa dengan adanya konsep diri membaca yang tinggi yang dimiliki pada siswa dapat memberikan dampak positif terhadap meningkatnya minat dan motivasi membaca pada siswa.

Hal ini didukung juga oleh hasil penelitian sebelumnya yang dilakukan Walgermo et al. (2018) bahwa memiliki konsep diri membaca memiliki hubungan yang positif dengan minat baca. Dengan adanya konsep diri membaca 
yang positif, maka para siswa-siswi secara internal akan terdorong untuk melakukan kegiatan membaca yang artinya bahwa minat baca siswa menjadi tinggi.

Temuan dalam penelitian ini didukung oleh penelitian Xia et al. (2019) bahwa minat baca yang tinggi dapat dicapai dan dipengaruhi oleh konsep diri membaca sehingga meningkatkan minat dan motivasi membaca pada anak. Ketika anak memiliki konsep diri membaca yang positif maka minat dan motivasi untuk melakukan kegiatan membaca menjadi tinggi. Penelitian yang dilakukan oleh Melekoğlu \& Wilkerson (2013) menemukan bahwa minat baca anak dapat diasah dan ditumbuhkan sejak dini, melalui faktor internal dari dalam diri yaitu konsep diri membaca. Anak-anak yang memiliki konsep diri membaca yang positif akan sangat berperan penting dalam meningkatkan kegemaran serta perilaku membaca. Mujan et al. (2019) dalam penelitiannya menjelaskan bahwa dengan adanya konsep diri yang positif dalam membaca, siswa akan semakin sadar akan pentingnya melakukan kegiatan membaca dengan minat dan dorongan yang tinggi sehingga perilaku membaca menjadi sebuah rutinitas bagi siswa.

Hasil penelitian ini dan beberapa penelitian sebelumnya menguatkan teori konsep diri membaca dari Chapman \& Tunmer (1995) bahwa konsep diri membaca dapat meningkatkan motivasi, kemampuan, dan minat siswa dalam membaca melalui 3 cara yaitu, pertama siswa memiliki persepsi kompetensi membaca yang positif dengan terus mengasah kemampuan kognitif dalam proses membaca mulai dari mengenal huruf, mengeja setiap kosakata, kalimat, paragraf dan sampai pada memaknai isi dari bacaan dalam proses membaca. Kedua persepsi kesulitan mengacu pada keyakinan bahwa kegiatan membaca itu terkadang ada kesulitannya, atau bermasalah, ketika anakanak dapat memiliki persepsi diri yang positif tentang proses membaca, maka anak akan mampu mengatasi dan melalui kesulitan membaca tersebut. Ketiga yaitu sikap membaca dimana mengacu pada komponen afektif dalam membaca, yang digambarkan dalam hal perasaan dan afinitas untuk membaca. Sikap ini menunjuk pada perasaan atau keadaan afektif siswa dalam memandang aktivitas membaca.

Dari hasil kategorisasi data sebelumnya dijelaskan bahwa kategorisasi minat baca siswa/i SDN "X" Sleman Yogyakarta didimonasi dalam kategori sedang dan beberapa siswa masuk dalam kategori rendah dan tinggi. Faktorfaktor penyebab rendahnya minat baca siswa menurut Sari (2018) dapat dilihat dari 2 faktor yaitu internal dan eksternal. Dari faktor internal, rendahnya minat baca siswa disebabkan oleh kemampuan membaca dan kurangnya kebiasaan membaca. Faktor eksternal penyebab rendahnya minat membaca siswa adalah lingkungan sekolah kurang mendukung, peran perpustakaan belum maksimal, keterbatasan buku/bahan bacaan, keluarga kurang mendukung, dan pengaruh menonton televisi, serta penggunaan handphone. Sehingga untuk menumbuhkan minat baca juga membutuhkan peran dari sekolah dan keluarga. Idris \& Ramdani (2015) menjelaskan bahwa sekolah memiliki peran yang besar terhadap usaha menumbuhkan dan membina minat baca siswa. Lingkungan sekolah yang belum mampu berperan atau terlibat secara serius dalam menumbuhkan minat membaca dapat menjadi salah satu penyebab rendahnya minat membaca siswa.
Selanjutnya keluarga merupakan sumber utama atau lingkungan yang utama penyebab rendahnya minat baca siswa. Hal ini dapat dilihat dari kebiasaan membaca di lingkungan keluarga yang masih rendah, kurangnya perhatian yang diberikan pada orang tua terhadap anak seperti, orang tua jarang mengajak anak ke toko buku atau menyediakan buku-buku bacaan terhadap anak (Asniar \& Silondae, 2020).

Sehingga perlunya partisipasi dan peran orangtua dalam meningkatkan minat baca. Penelitian dari Rahmawati \& Arnomo (2016) menyatakan bahwa orangtua dapat menumbuhkan minat membaca pada anak antara lain dengan melakukan aktivitas membaca di depan anak-anak, mengajak anak bermain tebak kata, memperkenalkan huruf-huruf kepada anak, mengajari anak mengeja dan atau membaca, mengajak anak ke toko buku dan membiarkan anak memilih buku yang disukainya, dan mengajak anak ke perpustakaan.

Kategorisasi data konsep diri membaca secara dominan berada dalam kategori tinggi dan diikuti dengan kategori sedang, dan tidak ada siswa yang masuk dalam kategori rendah. Hal ini berarti bahwa siswa/i SDN "X" Sleman - Yogyakarta memiliki konsep diri membaca yang tinggi. Tingginya konsep diri membaca merupakan bagian penting dari proses akademik dalam hal menghasilkan prestasi, mengembangkan serta meningkatkan kemampuan, minat, dan motivasi dalam membaca. Konsep diri membaca yang tinggi akan menjadikan siswa kreatif, berpikir kritis dan hasrat untuk meraih prestasi. Sehingga untuk mencapai hal tersebut siswa akan terdorong untuk melakukan kegiatan membaca dengan minat yang tinggi (Möller \& Pohlmann, 2010).

\section{Kesimpulan}

Berdasarkan hasil analisis data dan pembahasan terhadap hasil penelitian, maka dapat diambil kesimpulan bahwa hipotesis yang diajukan dalam penelitian ini dinyatakan diterima yaitu ada hubungan positif antara konsep diri membaca dengan minat baca. Semakin positif konsep diri membaca maka semakin tinggi minat baca. Sebaliknya, semakin negatif konsep diri membaca maka semakin rendah minat baca. Hal ini berarti bahwa konsep diri membaca memiliki kontribusi dalam meningkatkan minat baca pada siswa.

Implikasi dari penelitian ini adalah sekolah diharapkan mampu untuk menumbuhkan dan meningkatkan minat baca bagi siswa/siswi sejak di usia sekolah. Misalnya terus gencar dalam merancang program-program yang merangsang kegiatan membaca untuk meningkatkan budaya membaca sejak usia sekolah dasar, sehingga siswa sejak dini memiliki minat baca yang tinggi.

Partisipasi atau peran orang tua juga dibutuhkan. Orang tua agar bisa terlibat untuk proses perkembangan pembentuk konsep diri membaca di rumah, misalnya orang tua mendampingi anak untuk latihan membaca, mengeja, ataupun memberikan motivasi untuk anak agar terus mengembangkan konsep diri membaca, sehingga dengan konsep diri membaca yang positif akan berdampak pada tingginya minat baca.

Bagi peneliti selanjutnya yang ingin meneliti variabel tergantung yang sama dengan penelitian ini agar dapat 
mempertimbangkan faktor-faktor lain yang mempengaruhi minat baca seperti dari faktor eksternal yaitu pola asuh orangtua, dukungan sosial, konformitas, iklim keluarga dan sekolah, dan faktor-faktor lainnya.

\section{Referensi}

Adam, A. (2017). Hubungan minat baca dengan prestasi belajar bahasa indonesia bagi siswa kelas vi sd negeri 57 bulu-bulu kecamatan marusu kabupaten maros. Jurnal Kajian Pendidikan Dasar, 2(2), 314-324.

Anggraeni, R. (2019). Tingkat Baca Indonesia Masih Rendah, Sri Mulyani Gencarkan Literasi, diakses melalui https://ekbis.sindonews.com/berita/1444945/33.

Antari, D. N., Sundari, N., \& Wulan, N. S. (2016). Studi deskriptif minat baca siswa sekolah dasar kelas v di kota serang. Jurnal Antologi UPI, 4(2), 1-11.

Asniar, A., \& Silondae, D. P. (2020). Faktor-faktor penyebab rendahnya minat baca siswa. Jurnal Ilmiah Bening (Belajar Bimbingan dan Konseling), 4(1), 1-11. doi: http://dx.doi.org/10.36709/bening.v4i1.10484

Azwar, S. (2016). Reliabilitas dan validitas. Yogyakarta : Pustaka Pelajar.

Chapman, J. W., \& Tunmer, W. E. (1995). Development of young children's reading self-concepts: an examination of emerging subcomponents and their relationship with reading achievement. Journal of Educational Psychology, 87(1), 154161. doi: 10.1037/0022-0663.87.1.154

Chen, S., Sun, H., Zhu, X., \& Chen, A. (2014). Relationship between motivation and learning in physical education and after-school physical activity. Research Quarterly for Exercise and Sport, 85(4), 468-477. doi: 10.1080/02701367.2014.961054

Dalman, H. (2013). Keterampilan membaca. Jakarta : PT. Raja Grafindo Persada.

Darmono, (2007). Perpustakaan sekolah: Pendekatan aspek manajemen dan tata kerja, Jakarta: Grasindo.

Denessen, J. J. A., Zarrett, N. R., \& Ecless, J. S. (2007). I like to do it, i'm able, and i know i am: Longitudinal couplings between domain-specific achievement, self-concept, and interest. Child Development, 78(2), 430 - 447. doi: 10.1007/s10648-0139245-Z

Devi, A. A., \& Shanti, T. I. (2004). Peran ibu bekerja dan ibu rumah tangga di wilayah perdesaan dalam meningkatkan kemampuan membaca anak. Jurnal Ilmiah Psikologi “ARKHE”, 9(1), 1-10.

Harris A.J \& Sippay, E.R. (1980). How to in increase reading ability, A Guide To Development and Remedial Methods. New York: Longman.

Idris, M.H. \& Ramdani, I. (2015). Menumbuhkan minat membaca pada anak usia dini. Jakarta: Luxima.

Kartono, K. (1995). Perkembangan dalam memandu anak. Jakarta: PT. Rajawali.
Marlina, L., Caska, C., \& Mahdum, M. (2017). Hubungan minat baca dan motivasi belajar dengan hasil belajar ekonomi siswa kelas xi IPS SMAN 10 Pekanbaru. Jurnal Pendidikan Ekonomi dan Bisnis, 9(1), 33-47.

Melekoğlu, M. A \& Wilkerson, K.L. (2013). Motivation to read: How does it change for struggling readers with and without disabilities? International Journal of Instructions, 6(1), 77-88. doi/10.1177/0731948711421761

Mokoagow, K. (2016). Peranan surat kabar dalam menumbuhkan minat baca remaja di kecamatan singkil kota manado. Acta Diurna Komunikasi, 5(2), 1-6.

Möller, J., \& Pohlmann, B. (2010). Achievement differences and self-concept differences: Stronger associations for above or below average students? British Journal of Educational Psychology, 80(3), 435-450. doi: 10.1348/000709909X485234

Mujan, K., Sigan, D., \& Dawn, K. (2019). Value and self-concept: a study on reading habits among primary school students in sarawak. International Journal of Asian Social Science, 9(12), 709 -721. doi: 10.18488/journal.1.2019.912.709.721

Nursalina, A. I., \& Budiningsih, T. E. (2014). Hubungan motivasi berprestasi dengan minat membaca pada anak. Educational Psychology Journal, 3(1), 1-7.

Rahim, F. A. (2008). Pengajaran membaca di sekolah dasar. Jakarta: Bumi Aksara.

Rahmawati, N., \& Arnomo, I. (2016). Peran aktif ibu dalam menumbuhkan minat baca pada anak (studi deskriptif pada pekerja wanita di universitas hang tuah surabaya). Jurnal Humaniora, 13(2), 78-95.

Sabriyadi, S., Sumarna, N., \& Permana, T. (2015). Hubungan antara minat baca dengan prestasi belajar pada mata pelajaran produktif di smk. Journal of Mechanical Engineering Education, 2(1), 124-129.

Sari, C. P. (2018). Faktor-faktor penyebab rendahnya minat membaca siswa kelas IV. Basic Education, 7(32), 3-128.

Schiefele, U., Schaffner, E., Möller, J., \& Wigfield, A. (2012). Dimensions of reading motivation and their relation to reading behavior and competence. Reading Research Quarterly, 47(4), 427-463. doi: 10.1002/RRQ.030

Stoodt, B., Amspaugh, L., \& Hunt, J. (1996). Children literature. USA: Gosuch Scarisbrick Publisher.

Susilowati, S. (2016). Meningkatkan kebiasaan membaca buku informasi pada anak sekolah dasar. Jurnal Ilmiah Guru Caraka Olah pikir Edukatif, 20(1), 1-8.

Walgermo, B. R., Foldnes, N., Uppstad, P. H., \& Solheim, O. J. (2018). Developmental dynamics of early reading skill, literacy interest and readers' self-concept within the first year of formal schooling. Reading and Writing, 31(6), 1379-1399. doi: 10.1007/s11145-018-9843-8

Xia, T., Gu, H., \& Li, W. (2019). Effect of parents' encouragement on reading motivation: The mediating effect of reading selfconcept and the moderating effect of gender. Frontiers in Psychology, 10, 1- 7. doi: 10.3389/fpsyg.2019.00609 